\title{
Total losses and the peril of piracy in English law of marine insurance
}

\author{
Gotthard Gauci
}

Received: 28 February 2012 / Accepted: 7 March 2012 / Published online: 20 March 2012

(C) World Maritime University 2012

\begin{abstract}
Whereas the Marine Insurance Act 1906 provides substantial detail about total losses, very little is provided in relation to piracy in the said statute. The recent judgments in Masefield v Amlin by Steel J ([2010] 1Lloyd's Rep. IR 345) and then by the English Court of Appeal ([2011] EWCA Civ 24) have highlighted the difficulties associated with determining whether a seizure of the subject-matter of insurance, in this case cargo, by pirates, demanding a ransom, can give rise to a claim for a total loss. This is a very important matter which also raises issues of legality and public policy. This article examines the implications of this judgment against the backdrop of the English marine insurance definition of piracy and the intricacies of the law relating to constructive and actual total losses. The article concludes with the suggestion that possibly the marine insurance definition of piracy should tally with that in the domain of public international law, and further, that legislative intervention should be considered for the purpose of ascertaining the point in time whether and when seizure by pirates can constitute a total loss.
\end{abstract}

Keywords Piracy $\cdot$ Marine insurance $\cdot$ UK

\section{Introduction}

The Marine Insurance Act $1906^{1}$ goes into quite some detail in relation to the meaning and requirements for a claim for a total loss. The same cannot be said of the details in relation to the term "piracy".

Sections 56 through 63 of the statute elaborate on total losses of the two variants, actual and constructive. The first is frequently said to be one which is a total loss in fact and law, and the second is a total loss in fact only (Mustill and Gilman 1981). The notion of a constructive total loss has been applied to non-

${ }^{1}(6$ Edw 7 c 41$)$.

G. Gauci $(\bowtie)$

University of Plymouth, Plymouth, UK

e-mail: gotthard.gauci@plymouth.ac.uk 
marine cases, for instance, where although the loss is serious but not complete, the assured is paid for a total loss by the underwriter who becomes entitled to whatever remains of the subject-matter insured. ${ }^{2}$ In Mitsui v. Mumford, ${ }^{3}$ where the litigation related to a non-marine policy on goods, Bailhache $\mathrm{J}$ stated that in considering whether there had been a loss in terms of the contract, one would be right in taking note of those matters eligible for being taken into consideration if one were dealing with a question relating to constructive total losses in marine insurance. ${ }^{4}$ However, it is noteworthy that although abandonment is a consequence of payment for a total loss in every contract of indemnity, notice of abandonment is exclusive to marine insurance. $^{5}$ Although the notion of a constructive total loss can be fitted easily to traditional subject-matters of marine insurance like hulls and cargo, the same cannot be said with regard to liability insurance to which there is scant reference in the Marine Insurance Act $1906 .{ }^{6}$ A constructive total loss claim is dependent, in most instances ${ }^{7}$ on the giving of a notice of abandonment by the assured to the insurer; in the case of liability insurance, one cannot envisage the insurer accepting the abandoning of the subject-matter, which can hardly be anything other than a damnosa hereditas.

The peril of piracy, on the other hand, is relegated to Rule for the Construction of Policy Number 8 in schedule 1 of the Act. We are told, in very plain terms lacking definitional characteristics, that the term "pirates" includes passengers who mutiny and rioters who attack the ship from the shore.

\section{The definition of piracy}

The marine insurance precedent-based definition is at some substantial variance with the international law definition in the United Nations Convention on the Law of the Sea 1982. ${ }^{8}$ On the basis of current English case-law, we can say that for the purpose of marine insurance, a pirate must operate for personal greed, ${ }^{9}$ a requirement which tallies with the one in international law. In English marine insurance, piracy must also

\footnotetext{
${ }^{2}$ Parkington, Leigh-Jones, Longmore, Birds, MacGillivray \& Parkington on Insurance Law (1988 $8^{\text {th }}$ Edition) paragraph 1572 .

${ }^{3}$ [1915] 2 KB 27.

4 , at 32 .

${ }^{5}$ Id., at 31 .

${ }^{7}$ See Marine Insurance Act 1906, section 62 paragraphs 7, 8 and 9.

${ }^{8}$ UNCLOS 1982, article 101 provides: "Definition of Piracy.

Piracy consists of any of the following acts:

(a) any illegal acts of violence or detention, or any act of depradation, committed for private ends by the crew or the passengers of a private ship or a private aircraft, and directed:

(i) On the high seas, against another ship or aircraft, or against persons or property on board such ship or aircraft;

(ii) Against a ship, aircraft, persons or property in a place outside the jurisdiction of any State;

(b) any act of voluntary participation in the operation of a ship or of an aircraft with knowledge of facts making it a pirate ship or aircraft;

(c) any act of inciting or intentionally facilitating an act described in sub-paragraph (a) or (b)."
}

${ }^{9}$ Republic of Bolivia v. Indemnity Mutual Marine Insurance Co. [1909] KB 785. 
be accompanied by violence at the moment of appropriation. ${ }^{10}$ However, unlike international law, marine insurance law allows piracy to be constituted as such not only on the high seas, but also in territorial waters, as long as the vessel can be said to be at sea. ${ }^{11}$ Unlike international law, as is evident from the above quoted rule for the construction of policy, marine insurance piracy does not necessitate a pirate operating from a ship apart from the victim ship. The peril of piracy can possibly be covered not simply by the term "piracy" itself, but also under the heading of "persons acting maliciously", and the term "riots" (Gauci 2010). Lord Justice Rix, in the case of Masefield AG v. Amlin Corporate Member Ltd, ${ }^{12}$ did not exclude the possibility that piracy for ransom could constitute marine insurance theft, although, when a ransom is demanded, the issues of irretrievable deprivation or unlikelihood of recovery will be relevant in relation to whether there has been an actual or constructive total loss. One must note at this stage that marine insurance theft should be distinguished from theft in criminal law, in particular as a result of the marine insurance requirement of violence at the time of the appropriation. ${ }^{13}$

A distinguishing feature of modern-day piracy is the piratical intention to obtain the payment of a ransom, as distinct from the outright appropriation by the pirates of the ship or goods or both which appears to have been a dominant characteristic of piracy in days gone by. Obviously, in the case of outright appropriation, the indemnification by the insurer would be based on the loss of the appropriated items. On the other hand, in the case of piracy for ransom, the indemnification for the payment of the ransom by the shipowner is likely to raise the issue as to whether recovery should be in terms of the suing and labouring provision, or whether it is a case of general average. ${ }^{14}$ Furthermore, where an insured vessel is held for a substantial period of time for ransom by pirates, the issue arises as to whether such a loss of adventure by the insured could give rise to a valid claim for total loss, as will be discussed below.

\section{Actual total loss}

Actual total Loss is defined in section 57(1) of the Marine Insurance Act 1906. This provides:

Where the subject-matter insured is destroyed, or so damaged as to cease to be a thing of the kind insured, or where the assured is irretrievably deprived thereof, there is an actual total loss.

Templeman on Marine Insurance (Lambeth 1986) provides various examples, including destruction by fire, foundering in a hurricane by sea, and sinking in deep

\footnotetext{
${ }^{10}$ The Andreas Lemos [1982] 2 Lloyd's Rep. 483. See also Banque Monetaca \& Carystuiaki v. Motor Union Insurance Co. (1923) 14 L1.L. Rep. 48.

11 The Andreas Lemos [1982] 2 Lloyd's Rep. 483.

12 [ 2011] EWCA Civ 24, at paragraph 58.

13 See Marine Insurance Act 1906, Schedule 1, Rule for the Construction of Policy, number 9 which states that the term " "thieves' does not cover clandestine theft or a theft committed by any one of the ship's company, whether crew or passengers." See, further, The Andreas Lemos [1982] 2 Lloyd's Rep. 483.

14 See: Hicks v Palington (1590) 297; Royal Boskalis v Mountain (1999) QB 674 at 684-685. See, further, Gauci (2010).
} 
water after a collision. With continuous advances in technology, it becomes ever more difficult to state with certainty that, in the absence of complete and utter destruction, a subject-matter does indeed constitute an actual total loss; it has become more difficult to distinguish between an actual and a constructive total loss in cases where the subject-matter is destroyed but there is a technical possibility of reconstitution. The instance of irretrievable deprivation is probably even more problematic. Templeman (Lambeth 1986) states that: "irretrievable deprivation includes capture or seizure, and implies that although the subject-matter insured may be actually in existence, the assured will never again regain possession of it: for instance, capture by enemy in time of war and condemnation as lawful prize."

Whether a loss by piracy could give rise to an actual total loss was addressed by the Court of Appeal in the recent case of Masefield AGv Amlin Corporate Member. ${ }^{15}$ In the leading judgment of Rix LJ, the possibility of an actual or even a constructive total loss in the case of piracy for ransom is not excluded. Though possible, such an event can only mature into an actual or constructive total loss. In relation to the appeal in relation to an actual total loss, Rix LJ made the following significant statement:

The subject-matter is not amenable to a rule of law at all: it is all ultimately a question of fact. The typical case of capture, by a nation's warship, subject to condemnation as a prize, is not an ATL, although it may mature into one. Piratical seizure, in the absence of a policy of ransom, may amount to an ATL, where the pirates escape with their prize for their own use and there is no prospect whatever of finding or recovering vessel or cargo: but where a chance of recapture remains even such a seizure will not give rise to an immediate ATL, and in any event that is very far from this case. ${ }^{16}$

A strong argument on the part of the claimant was that, if one ignores the request of a ransom payment, then the issue of whether there has been an actual total loss would become easier, indeed there would be irretrievable deprivation for the purpose of section 57 of the Marine Insurance Act 1906. The claimant argued that the payment of a ransom should be considered as being against public policy. This is a matter which raises difficult issues to resolve. At paragraph 62 of the appellate judgment in Masefield $v$ Amlin, Lord Justice Rix referred to a citation from Egerton $v$ Brownlow ${ }^{17}$ by Park B in Fender $v$ St John Mildnay ${ }^{18}$ that "the doctrine [of public policy] should only be invoked in clear cases in which the harm to the public is substantially incontestable, and does not depend upon the idiosyncratic inferences of a few judicial minds." Further, Rix LJ confirmed that the payment of ransoms is no longer illegal, ${ }^{19}$ and that there is authority based on an obiter that the payment of a ransom can constitute a sue and labour expense ${ }^{20}$; reference was further made to a statement in Arnould which had been cited in the Royal Boskalis appellate judgment ${ }^{21}$ that:

\footnotetext{
$\overline{15}$ [2011] EWCA Civ 24; [2011] Lloyd's Rep. 338.

${ }^{16} \mathrm{Id}$., at paragraph 56.

17 (1853) 4 HL Cas 1.

18 [1938] AC 1.

${ }^{19}$ [2011] EWCA Civ 24, at paragraph 63.

${ }^{20} I d$., at $\$ 64$.

${ }^{21}$ [1999] QB 674.
} 
There appears to be little doubt that where a payment which is not illegal under any relevant law is made to secure the release of property, this can be recovered even though the persons demanding the payment are not acting lawfully in doing so. Thus, for example, payment to recover property from hijackers must, it is submitted, in general be recoverable. ${ }^{22}$

However, Pill LJ in the same judgment does cast some doubt as to whether this was completely correct:

I should like to leave open for further consideration the question not taken in the present case: whether a sue and labour clause covers payments made under threat of total loss, from whatever source, which are totally repugnant to English notions of legality. Is the payment of a type the law should recognise as entitling the payer to claim as sue and labour, given a public interest in the issue of extortion of money from ship owners in circumstances of duress and illegality? Payment in face of such a threat may be reasonable within the meaning of that word in section 78(4) of the Act of 1906 but knowledge that such payment is recoverable from insurers may have the effect of encouraging such threats.... ${ }^{23}$

Lord Justice Rix was, however, clearly of the opinion that even though pirates were considered to be enemies of mankind and that an agreement to pay a ransom was unenforceable, "there is no universal morality against the payment of ransom, the act not of the aggressor but of the victim of piratical threats, performed in order to save property and the liberty or life of hostages." 24 Indeed, Rix LJ described the situation where the government stands aloof in relation to ransom payments to pirates as "something of an unexpressed complicity." 25 Furthermore, the claimants' submission could not succeed as the ransom payment had already been paid by the third party ship owners. $^{26}$

Although the Masefield judgment leaves little, if at all any, room for distinction between illegality and public policy, it can be justified on the basis that human life as well as property was at risk of destruction by pirates. A set of facts where only ship and/or cargo is only at risk might well be the object of judicial distinction in the future, even if the payment of ransom to pirates remains legal.

\section{Constructive total losses}

The preamble to the Marine Insurance Act 1906 provides that the intention of the legislators was to codify the law relating to marine insurance, and in Section 60 defines a constructive total loss in the following words:

(1) Subject to any express provision in the policy, there is a constructive total loss where the subject-matter insured is reasonably abandoned on account of its actual total loss appearing to be unavoidable, or because it could not

\footnotetext{
${ }^{22}$ See Masefield v. Amlin [2011] EWCA Civ 24 at $\$ 64$

${ }^{23}$ As cited in $\$ 65$ of Masefield v. Amlin [2011] EWCA Civ 24.

${ }^{24}$ Loc. cit., at $\$ 66$.

${ }^{25}$ Loc. cit., at $\$ 71$.

${ }^{26}$ Loc. cit., at $\$ 77$.
} 
be preserved from actual total loss without an expenditure which would exceed its value when the expenditure had been incurred.

(2) In particular, there is a constructive total loss -

(i) Where the assured is deprived of the possession of his ship or goods by a peril insured against, and (a) it is unlikely that he can recover the ship or goods, as the case may be, or (b) the cost of recovering the ship or goods, as the case may be, would exceed their value when recovered; or

(ii) In the case of damage to a ship, where she is so damaged by a peril insured against, that the cost of repairing the damage would exceed the value of the ship when repaired.

In estimating the cost of repairs, no deduction is to be made in respect of general average contributions to those repairs payable by other interests, but account is to be taken of the expense of future salvage operations and of any future general average contributions to which the ship would be liable if repaired; or

(iii) In the case of damage to goods, where the cost of repairing the damage and forwarding the goods to their destination would exceed their value on arrival.

Details about the procedure for claiming a constructive total loss, in particular the general necessity of providing a notice of abandonment, are provided in section 62 of the Marine Insurance Act $1906 .^{27}$

It is strongly arguable that the section 60(2)(i)(a) reference to unlikelihood of recovery [within a reasonable time] does not sit comfortably with the situation of reasonable abandonment on account of an actual total loss appearing to be unavoidable. However, this view can be avoided by giving the term "unavoidable" an expansive interpretation.

\section{Loss of possession and total losses}

The part of section 60 which is directly relevant to the case of piracy for ransom is subparagraph 2 and specifically subparagraph 2(a) which refers to the instance where the assured is deprived of the possession of the ship or goods by a peril insured against, and (a) it is unlikely that he can recover the ship or goods. This provision can be contrasted with a requirement of a specific case of actual total loss in section 57(1) of the Marine Insurance Act 1906 which identifies the case where the assured is irretrievably deprived of the subject-matter insured. The two different instances of a total loss, one constructive and the other actual, are examples of the distinguishing features of the two types of total losses as specified by Arnould (Mustill and Gilman 1981), i.e. one a total loss in law but not in fact and the other, a total loss in both law and fact.

When piracy results in a request for ransom, the initial loss is likely to be one very similar to that occasioned by the peril of detainment. Detainment originally was included in a wide clause, namely, "arrests, restraints, and detainments of all kings,

\footnotetext{
${ }^{27}$ See, further, The Kastor Too [2004] EWCA Civ 277.
} 
princes and people...."28 Rule for the construction of policy number $10^{29}$ excludes loss caused by piracy as part of the arrest etc. clause. It specifically provides that "the term 'arrests, etc., of kings princes and people' refers to political or executive acts, and does not include a loss caused by riot or by ordinary judicial process." In the context of constructive total loss, the matter of deprivation of possession is of crucial importance, and is one which was discussed and elaborated on in the well-known arbitral award by Mr Justice Staughton in the case of The Bamburi. ${ }^{30}$ In that case, the vessel with that name had been restrained and detained by the Iraqi authorities in the Shatt al Arab waterway at the time of the Iran-Iraq war. A skeleton crew remained on the vessel, but there was no Iraqi presence on the vessel, nor was there any proprietary assertion by the Iraqi authorities in relation to her. The owners had, however, been wholly deprived of the "free use and disposal of the vessel", in the sense that their trading with her had ceased. One question was whether the loss of the free use and disposal of the vessel was tantamount to the loss of possession of the same subject-matter insured by a peril insured against, namely, "arrests, restraints and detainment...". Finding that a loss of adventure could constitute a constructive total loss is undoubtedly easier to ascertain in a cargo policy than in a hull policy; this is because traditionally a cargo policy, unlike a hull policy, has been treated as an insurance of the adventure, particularly as a result of the inclusion in the former of the forwarding charges clause. ${ }^{31}$

The arbitrator in The Bamburi, after examining the relevant case-law, which was inconsistent, was of the view that possession had been lost. In the case of Panamanian Oriental $v$ Wright $^{32}$ case, Mr Justice Mocatta had approved in broad terms the so called free use and disposal test, to the effect that possession is lost if the free use and disposal is lost.

Mr Justice Staughton, as arbitrator in The Bamburi, took the same view as $\mathrm{Mr}$ Justice Mocatta, and justified his decision by the following statement:

It may well be that the law took a wrong turning in 1857 . But in my opinion it is far too late now for me to reverse that error, if error it was. I prefer the view that, when Parliament used the word 'possession' in 1906 - a word which, it is conceded, may have a wider or narrower meaning — the intention was to reenact what had apparently been settled law for nearly fifty years. The cases since the Act lend some support to either view, but on balance I consider that

\footnotetext{
${ }^{28}$ See Lloyd's S.G. policy in the first schedule to the Marine Insurance Act 1906.

${ }^{29}$ Marine Insurance Act 1906, Schedule 1.

${ }^{30}$ [1982] 1 Lloyd's Rep. 312.

31 An exemplar of this clause is clause 12 of the Institute Cargo Clauses B (1/1/1982), which states as follows:
}

"Where, as a result of the operation of a risk covered by this insurance, the insured transit is terminated at a port or place other than that to which the subject-matter is covered under this insurance, the Underwriters will reimburse the Assured for any extra charges properly and reasonably incurred in unloading storing and forwarding the subject-matter to the destination to which it is insured hereunder.

This Clause 12, which does not apply to general average or salvage charges, shall be subject to the exclusions contained in Clauses 4, 5, 6 and 7 above, and shall not include charges arising from the fault negligence insolvency or financial default of the Assured or their servants."

32 [1971] 1 Lloyd's Rep. 487. 
they are more in favour of the 'free use and disposal' construction than against it. $^{33}$

It is to be noted that particular reference is made in the award to the cases of Rotch v. Edie ${ }^{34}$ and Peele v. The Merchants' Insurance Company. ${ }^{35}$ Despite the time lapse, the facts in The Bamburi bear striking similarity to the facts in the 1795 case of Rotch v. Edie, where the insured vessels were held up by an embargo in French ports. In the case of Peele v. The Merchants' Insurance Company, Mr Justice Story sitting in the Circuit Court in the District of Massachusetts, in an erudite judgment, analysed and discussed the law relating to constructive total losses and abandonment. In an early part of the judgment which related to the vessel which had been shipwrecked, $\mathrm{Mr}$ Justice Story stated:

It has been very justly stated, that a loss in the contemplation of law does not necessarily suppose the actual destruction of the thing insured. It may technically exist, when the thing is in safety, but is for the time being lost to the owner, or taken from his free use and possession. Such are the common causes of total loss by capture, by embargoes, and by restraint and detainments of princes. ${ }^{36}$

\section{The test of unlikelihood of recovery}

The test in relation to unlikelihood of recovery of possession in section 60(2)(i) of the Marine Insurance Act 1906 has created a number of difficult issues. Firstly, there is implicit within section 60 that the reference is to unlikelihood "within a reasonable time". 37 Secondly, the relevant point in time to assess the unlikelihood is the date of the issue or notional issue of the writ/claim form. ${ }^{38}$ What happens after that date to the subject-matter of the insurance, should, at one level, be considered to be irrelevant. ${ }^{39}$ However, judicial practice takes a more pragmatic approach, in that happenings after the commencement of litigation may well be of

\footnotetext{
33 (1982) 1 Lloyd's Rep. 312 at p. 320.

34 (1795) 6 TR 413.

35 (1822) 3 Mason's Rep. 27.

36 (1822) 3 Mason's Rep. 27 at p. 40.

37 See The Bamburi [1982] 1 Lloyd's Rep. 312 at 314 and authorities there cited.

${ }^{38}$ Marstrand Fishing Co. Ltd v. Beer (The Girl Pat) (1936) 56 Ll. L. Rep. 163 at 173 where the decision in Polurrian Steamship Company Ltd v. Young (1915) 1 KB 922 is applied. In The Polurrian case (1915 1 K.B. 922 at 927-928), the Court of Appeal had remarked as follows: "Now it is indisputable that, according to the law of England, in deciding upon the validity of claims of this nature between the assured and the insurer, the matters must be considered as they stood at the commencement of the action. That is the governing date. If there then existed a right to maintain a claim for a constructive total loss by capture, that right would not be affected by a subsequent recovery or restoration of the insured vessel."

${ }^{39}$ Collins J in Ruys $v$ Royal Exchange, (1897) 2 QB 135 at 142, justified this approach as a matter of convenience: "But the object of litigation being to settle disputes, it is obvious that some date must be fixed upon when the respective rights of the parties may be finally ascertained, and the line of the writ may be regarded as a line of convenience which has been settled by uniform practice for at least seventy years...". Similarly, §15-11 of the Norwegian Marine Insurance Plan provides in sub-paragraph 4 that: "If the assured has brought a claim for a total loss and the time-limits stipulated have expired, it is irrelevant for the assured's claim that the ship is released at a later time."
} 
informative value to the adjudicator. In the case of Masefield v. Amlin, in the judgment by the court of first instance, Steele J. made the following significant pronouncement, albeit in the context of the claim for an actual total loss:

Although the actual fact of recovery within a short period is not directly material let alone decisive, the court is entitled to consider what in fact happened after the relevant date as this 'may assist in showing what the probabilities really were, if they had been reasonably forecasted' ${ }^{40}$

\section{Reasonable time}

What constitutes a reasonable time is not specified in the Marine Insurance Act 1906. We are simply told that, in this respect, what is reasonable is a question of fact. ${ }^{41}$ Reasonable time for the purpose of ascertaining whether there was unlikelihood of recovery of the Bamburi within a reasonable time was held to be a period of 12 months. $^{42}$

A degree of certainty in relation to the risk of detainment and related risks is provided by Clause 3 (Detainment) of the Institute War and Strikes Clauses (Hulls Time $)^{43}$ and the Institute War and Strikes (Hulls Voyage) ${ }^{44}$; such clause provides:

In the event that the vessel shall have been the subject of capture seizure arrest restraint detainment confiscation or expropriation, and the Assured shall thereby have lost the free use and disposal of the vessel for a continuous period of 12 months then for the purpose of ascertaining whether the Vessel is a constructive total loss the Assured shall be deemed to have been deprived of the possession of the Vessel without any likelihood of recovery. ${ }^{45}$

\footnotetext{
40 The judgment [(2010) EWHC 280 (Com) at §29] cited, in this respect, the 1919 case of Bank Line $v$. Capel (H.L. [1919] AC 435).

41 Marine Insurance Act 1906, section 88.

42 (1982) 1 Lloyd's Rep. 312 at 322.

$431 / 10 / 1983$, and $1 / 11 / 1995$.

$441 / 10 / 1983$ and $1 / 11 / 1995$.

45 It may be noted that The Norwegian Marine Insurance Plan 1996, Version 2010, provides details as to when a partially damaged can be treated as a "condemned vessel", i.e. a total loss, in:
}

"§ 11-3. Condemnation

The assured may claim compensation for a total loss if the conditions for condemnation of the ship are met. The conditions for condemnation are met when casualty damage is so extensive that the cost of repairing the ship will amount to at least $80 \%$ of the insurable value, or of the value of the ship after repairs if the latter is higher than the insurable value. If two or more insurances have been effected against the same perils but with different valuations, the highest valuation shall form the basis of the calculation.

The value of the ship after repairs shall be determined on the basis of the market value at the time when the assured makes his request for a condemnation.

Casualty damage shall be deemed to include only such damage as has been reported to the insurer concerned and surveyed by him in the course of the last three years prior to the casualty that gives rise to the request for condemnation. Costs of repairs are deemed to include all costs of removal and repairs which, at the time when the request for condemnation is submitted, must be anticipated if the ship is to be repaired except, however, salvage awards or compensation for depreciation in value under $\S 12-1$, paragraph 4." 
However, as has been discussed elsewhere (Gauci 1996), whereas the clause provides a degree of certainty after the lapse of 12 months, whether it displaces the possibly more favourable provisions of the Marine Insurance Act 1906 is a moot point.

It is worthy of note that paragraph $15-11$ of the Norwegian Marine Insurance Plan 1996, Version 2010, applies to the risk of piracy a rule similar to that applied to detainment by the English Detainment clause referred to earlier. The Norwegian Plan provides specifically that "if a ship has been captured by pirates or taken away from the assured by similar unlawful interventions, for which the insurer is liable under paragraph $2-9$, the assured may claim for a total loss if the ship has not been recovered within 12 months from the day when the intervention took place." However, the Norwegian Plan is clearer than the aforementioned English clause in that it makes it clear that the assured need not wait for the expiry of the 12-month period before making a claim for the total loss "if it has been established before expiry of the time-limits...that the assured will not recover the ship."46

\section{Abandonment}

Abandonment in the law of marine insurance is also found in non-AngloSaxon marine insurance legislation. For instance, a similar notion of abandonment features in the Italian Codice della Navigazione, ${ }^{47}$ where article 540 (c) provides that a vessel may be abandoned and a claim lodged for a total loss where the amount of expenses for the repair of material damages reaches three-quarters of her insurable value. Article 546 furthermore specifically deals with the effects of abandonment and provides for a specific time-limit within which the underwriter can declare that he does not wish to take advantage of the abandonment; in default, the underwriter becomes the owner of the abandoned subject-matter. A similar feature of abandonment also exists in French law, and is known as delaissement, which has been said to have appeared for the first time in the Guidon de la Mer in the 15th century. $^{48}$

Section 61 of the Marine Insurance Act 1906 provides that "where there is a constructive total loss the assured may either treat the loss as a partial loss, or abandon the subject-matter insured to the insurer and treat the loss as if it were an actual total loss." The procedure of giving a notice of abandonment to the underwriter must be followed by the insured. ${ }^{49}$ The term "abandon" in section 61 received judicial attention in the judgment of the court of first instance in Masefield $A G v$. Amlin Corporate Member Ltd, ${ }^{50}$ where Steel J. referred to the judgment of Scott LJ in

\footnotetext{
$\overline{46}$ Paragraph 15-11, sub-paragraph 3.

47 Articles 540-546. The Code here referred to is the one updated as at 31 January 1994. In the case of Roux v Salvador (1836) 3 Bing. (N.C.) 266, Lord Abinger CB looked at the history of abandonment in the context of marine insurance law, and referred to abandonment in the civil statutes of Genoa dating to 1610.

${ }^{48}$ See Rodiere et al, Droit Maritime - Assurance et Ventes Maritime (1983), p. 188.

${ }^{49}$ Marine Insurance Act 1906, section 62.

50 [2010] EWHC 280 (Comm), §55.
} 
Court Line v. $R^{51}$ where the following had been stated in relation to the requirements for a claim of a constructive total loss as in the case of piracy for ransom:

When the ship is spoken of as 'abandoned on account of its total loss appearing to be unavoidable', the word [abandoned] is used in nearly the same sense as when according to the law of salvage the ship is left by master and crew in such a way as to make it a 'derelict', which condition confers on salvors a certain but not complete exclusiveness of possession, and a higher measure of compensation for salvage services. But to constitute the ship a 'derelict', it must have been left: (a) with that intention (animo derelinquendi)...; (b) with no intention of returning to her; and (c) with no hope of recovering her. ${ }^{52}$

Scott LJ in the said judgment, in distinguishing between abandonment and notice of abandonment, went on to state that:

In Sect. 61 the word 'abandonment' seems to import an act on the part of the assured, but in truth it amount usually to nothing more than his making up his mind to give notice of abandonment to the insurer under Sect. 62(1), at the peril of losing his right of election under Sect. 61. The legal consequences of a notice of abandonment if accepted by, or established as valid against, the insurer is to pass the property to the underwriter as abandonment to him under Sect. 61. A valid 'abandonment' in Sect. 63 necessarily means an abandonment by the assured to the insurer and passes the property to him.

Abandonment is actually a feature of indemnity contracts and it finds an application in the law of marine insurance; as Brett LJ stated in Kaltenbach v. Mackenzie, ${ }^{53}$ when referring to the case of Rankin v. Potter ${ }^{54}$ :

...abandonment is not peculiar to policies of marine insurance; abandonment is part of every contract of indemnity. Whenever, therefore, there is a contract of indemnity and a claim under it for absolute indemnity, there must be an abandonment on the part of the person claiming indemnity of all his right in respect of that for which he receives indemnity.

However, in the case of a total loss, whether of the actual or the constructive type, the insurer can elect whether to take over ownership of the abandoned item. This is hinted strongly as being the case in section 63 of the Marine Insurance Act 1906, despite the statement by Scott LJ above that section 63 necessarily meant "an abandonment by the assured to the insurer" whereby property passes to the insurer. The question then arises as to whether an insured abandoning sine spe revertendi divests himself of ownership of that item and concurrent responsibilities. If the underwriter declines to take over the interests of the assured in the subject-matter, the question which necessarily presents itself is whether the abandonment of what

\footnotetext{
51 (1944) 78 L1. L. Rep. 390.

52 That is, sine spe recuperandi, as is stated in some salvage cases.

${ }^{53}$ CPD III 1878, p. 467, at 470-471.

54 [1873] Law Rep. 6 HL 83.
} 
should amount to a derelict constitutes a mechanism whereby the owner divests himself of ownership. This question is obviously relevant where liability for damage caused by a ship attaches to whoever is the owner as in the case of the International Convention on Civil Liability for Oil Pollution Damage 1992 (CLC 1992), or similar provision in other legislation. In the case of Boston Corporation v. France Fenwick and Co Ltd, ${ }^{55}$ where an action was instituted by plaintiffs to recover from the defendants, owners of the vessel Lockwood, the expenses incurred for wreck removal, the first defence raised by the defendants was that they were not owners of the wreck at the time the expenses were incurred. In that case, the notice of abandonment tendered by the insured had been refused by the underwriters. Bailhache J., in his judgment, stated:

On principle it must be borne in mind that in the case of a constructive total loss an owner can only abandon to his underwriters. Having done this, he divests himself of his property in the thing abandoned and ceases to be its owner. ${ }^{56}$

The Judge furthermore states, in the last paragraph of his judgment, that:

I have refrained from expressing any opinion whether a valid notice of abandonment, unaccepted by underwriters, while it divests the owner of his property in the wreck at the same time automatically transfers the property to the underwriters. I will only say that there is a good deal to be said against this view in favour of the wreck becoming in such circumstances a res nullius. This point does not call for decision. ${ }^{57}$

Similarly, in the earlier case of The Crystal, ${ }^{58}$ the issue related to wreck removal expenses. It was decided that at the time the removal expenses were incurred, the owners had abandoned the vessel as derelict and had given notice of abandonment to underwriters. It was held that the defendants were not liable for the removal expenses on the ground that they were not owners at the material time. ${ }^{59}$

However, such an approach was not adopted in the later case of Ocean Steam Navigation Company Ltd v. Evans, ${ }^{60}$ where Greer LJ stated that "it does not follow that, because notice of abandonment is given to an insurer, therefore the vessel, which may have some value is abandoned to all the world, or that it has no owner at all, and becomes what lawyers prefer to describe, using the Latin language, a res nullius. "61 A similar approach is taken by the editors of the 16th edition of Arnould's Law of

\footnotetext{
55 [1923] 39 T.L.R. 441.

56 Ibid., at 443.

57 Ibid., at 444 .

58 [1894] AC 508, HL.

59 [1894] AC 508, at 518-519, 521, 527, 532.

${ }^{60}$ (1934) XL Com. Cas. 108, CA, at p. 111.

61 This obiter is cited with approval in an obiter by Cohen L.J. in Blane Steamship Ltd v. Minister of Transport (1951) 2 K.B. 965 at 991. The term res nullius harks back to Roman Law. According R.W. Lee, The Elements of Roman Law, at p. 110, "The phrase res nullius is used in various senses: (a) to include all things which according to Roman ideas are not susceptible of private ownership; (b) specifically, as above, of things sacred, religious and sanctioned; (c) of things which, though susceptible of ownership, are not at the moment owned, e.g. wild animals uncaptured, or things which have been abandoned by their owner (res derelictae)."
} 
Marine Insurance and Average, ${ }^{62}$ where reference is made to the law of trusts case Vandervell v. IRC ${ }^{63}$ where Plowman J stated:

As I see it, a man does not cease to own property simply by saying 'I don't want.' If he tries to give it away the question must always be, has he succeeded in doing so or not.

Moreover, it is strongly arguable that whereas abandonment of an object at sea as res derelicta was likely to have been acceptable in Roman times and even later, it is generally not acceptable in modern times. Indeed, dumping at sea is highly regulated in international environmental law, and although a ship or cargo may indeed constitute res derelicta in terms of, for instance, the Merchant Shipping Act 1995, this can only be legally done in a small number of cases. Moreover, dumping at sea is a highly regulated area of the law, and "with limited exceptions the dumping of waste at sea is now illegal" (Birnie et al. 2009). One can at this point refer to Article 210 of UNCLOS 1982, ${ }^{64}$ which provides in Article 210, paragraph 1, that "States shall adopt laws and regulations to prevent, reduce and control pollution of the marine environment by dumping." 65 The London Dumping Convention Protocol of 1996 is a very strong international law mechanism, and constitutes a very effective application of the precautionary approach in environmental regulation (Birnie et al. 2009).

At this point, one would wonder about the continued stipulation provided for instance in the Britania Steam Ship Insurance Association Limited 2011 Protection and Indemnity Rules, which provide in paragraph 3 of Rule 21 that "in the event of an Entered Ship becoming an actual or constructive total loss, the Association shall, subject to the hull underwriters' rights in the matter, be entitled to request the Member concerned to abandon the Ship to the Association or to such other person (including the world at large) as the Association shall nominate."66 The same paragraph furthermore provides that "if the Member concerned does not abandon the Ship having received such a request from the Association, the Association shall not be responsible for any claim that could have been avoided had the Member abandoned the ship as aforesaid, and the burden of proving that the claim could not have been avoided by such abandonment shall be upon the Member." Such a provision would protect the Protection and Indemnity Club if the owner refuses to abandon when there is a prospect of liability for wreck removal. However, it is unlikely that such provisions would these days be interpreted in such a manner as to allow an owner and his insurer to avoid liability through the mechanism of abandonment to the world at large. Indeed it is likely that legislative action in this respect should not be necessary, and legislative action in the United States Oil Pollution Act ${ }^{67}$ to extend the definition of responsible person for oil pollution to include "the persons who would have been responsible parties immediately prior to the abandonment of the vessel" ${ }^{\prime 68}$ was made ex abundantia cautela.

\footnotetext{
${ }^{62}$ Op. cit., at $\$ 1290$.

63 [1966] Ch. 261.

64 United Nations Convention on the Law of the Sea 1982.

${ }^{65}$ See, further, article 216 of the same Convention.

${ }^{66}$ Emphasis added.

${ }^{67}$ Public Law 101-380 (H.R. 1465); 18 August 1990.

${ }^{68}$ United States Oil Pollution Act 1990,§1001 (32) (F).
} 


\section{Conclusion}

Amendments to the Marine Insurance Act 1906 have been very few and far between, and a bill currently before Parliament perhaps promises to be the first substantive amendment of the statute since its birth in $1906 .{ }^{69}$ Difficulties encountered by the industry have mostly been addressed by amendments to the standard form contracts available on the London market, and some have largely been clarified, as in the case of abandonment and notice of abandonment, by judicial intervention. At some point in the future, a decision will have to be made whether or not to come up with a legislative or contractual definition of marine insurance piracy which tallies with that in the domain of public international law. Perhaps the most difficult issue remains as to the point in time, if at all, when a seizure by pirates can constitute a total loss; this difficulty is likely to be alleviated if the payment of a ransom to pirates is outlawed in the same way as it is in relation to terrorists.

\section{References}

Birnie P, Boyle A, Redgwell C (2009) International law and the environment. 3rd edn, p. 466. Oxford University Press, Oxford

Gauci G (1996) Constructive total losses in the law of marine insurance (Chapter 6). In Thomas DR (ed) The modern law of marine insurance. LLP, London, pp. 212-213

Gauci G (2010) Piracy and its legal problems: with specific reference to the English law of marine insurance. J Maritime Law Commerce 41(4):541, 550-552

Lambeth RJ (1986) Templeman on marine insurance. 6th edn, p. 212. Pitman, London

Mustill MJ, Gilman JCB (1981) Arnould's law of marine insurance and average. 16th edn., Vol. 2, p. 594. Stevens, London

${ }^{69}$ Consumer Insurance (Disclosure and Representations) Bill (HL Bill 68). 